Vol. 8, No. 1

Tahun 2022

\section{Article History}

Received: 16/10/2021

Revised: 28/11/2021

Published: 31/12/2021

\section{Citation Suggestion:}

Muhammad Ilham, A. Sakti R.S. Rakia, Wahab Aznul Hidaya, Dwi P. Markus \& Masrifatun Mahmudah.

(2022). Proses Penyelesaian Tindak Pidana Berdasarkan Adat Suku Moi (Studi Kasus di Polres Kota Sorong). JUSITISI, 8 (1), 40-54

\title{
Proses Penyelesaian Tindak Pidana Berdasarkan Adat Suku Moi (Studi Kasus di Polres Kota Sorong)
}

Muhammad Ilham ${ }^{1}$, A. Sakti R.S. Rakia², Wahab Aznul Hidaya ${ }^{3}$, Dwi P. Markus $^{4}$, Masrifatun Mahmudah ${ }^{5}$.

${ }^{1}$ Fakultas Hukum, Universitas Muhammadiyah Sorong.

Email : muhamadilhamm150@gmail.com

${ }^{2}$ Fakultas Hukum, Universitas Muhammadiyah Sorong.

Email : saktialwiyah@um-sorong.ac.id

${ }^{3}$ Fakultas Hukum, Universitas Muhammadiyah Sorong.

Email : wahabaznulhidaya@um-sorong.ac.id

${ }^{4}$ Fakultas Hukum, Universitas Muhammadiyah Sorong.

Email : dwypratiwimarkus@gmail.com

${ }^{5}$ Fakultas Hukum, Universitas Muhammadiyah Sorong.

Email : masrifatun.mm@gmail.com

\begin{abstract}
The existence and habits that live into the rule of law for indigenous peoples within the framework of the Unitary State of the Republic of Indonesia still exist and are developing. This study aims to analyze the process of resolving criminal acts based on the Moi tribal custom (a case study at the Sorong City Police Station). This study uses a juridical empirical research method. Data collection techniques are carried out by conducting field studies (field research). The results of this study indicate that the enforcement of customary law against criminal acts based on Moi customs is influenced by the respect of the Moi indigenous people who highly uphold customs as a way of life. Meanwhile, the cause of the use of the Moi custom in the process of solving problems in the Moi custom is considered more fair and represents the inner atmosphere of the Moi tribal community, and provides a more deterrent effect on the perpetrators, and is also related to the supernatural punishments that are believed to be faced by the perpetrators.
\end{abstract}

Keywods: Customs; Customary law; Customary Crime; Moi tribe.

\begin{abstract}
Abstrak: Keberadaan serta kebiasan-kebiasaan yang hidup menjadi aturan hukum masyarakat adat dalam bingkai Negara Kesatuan Republik Indonesia hingga saat ini masih eksis dan mengalami perkembangan. Penelitian ini bertujuan untuk menganalisis mengenai proses penyelesaian tindak pidana berdasarkan adat suku moi (studi kasus di polres kota sorong). Penelitian ini menggunakan metode penelitian empiris yuridis. Teknik pengumpulan data dilakukan dengan cara melakukan studi lapangan (field reseach). Hasil penelitian ini menunjukan bahwa penegakkan hukum adat terhadap tindak pidana berdasarkan adat Moi dipengaruhi oleh penghormatan masyarakat adat Moi yang sangat menjunjung tinggi adat
\end{abstract}


istiadat itu pedoman hidup. Sementara itu, penyebab digunakan adat Moi dalam proses penyelesaian masalah di adat Moi dianggap lebih adil dan mewakili suasana kebatinan masyarakat suku Moi, serta lebih memberikan efek jera pada pelaku, dan juga berkaitan dengan hukuman ghaib yang dipercaya akan dihadapi oleh pelaku.

Kata Kunci : Adat; Hukum Adat; Pidana Adat; Suku Moi.

\section{PENDAHULUAN}

Keberadaan masyarakat hukum adat di Indonesia pada dasarnya tidak dapat dipisahkan dari pembentukan negara Indonesia itu sendiri, mengingat eksistensi masyarakat hukum adat telah lama eksis jauh sebelum bangsa Indonesia merdeka secara berdaulat. Namun demikian, dalam UUD 1945 sebelum amandemen, tidak ada satu pun ketentuan dalam konstitusi yang secara tegas memuat klausul mengenai eksistensi masyarakat hukum adat. Klausul mengenai eksistensi masyarakat hukum adat baru tercantum dalam UUD NRI 1945 sesudah amandemen perubahan kedua, yakni pada Pasal 18B ayat (2), yang berbunyi :

"Negara mengakui dan menghormati kesatuan-kesatuan masyarakat hukum adat beserta hak-hak tradisionalnya sepanjang masih hidup dan sesuai dengan perkembangan masyarakat dan prinsip Negara Kesatuan Republik Indonesia, yang diatur dalam undang-undang".

Frasa "yang diatur dalam undang-undang" pada Pasal 18B ayat (2) ini pada hakikatnya memerintahkan agar selanjutnya dibentuk undang-undang yang memuat segala hal yang berkaitan dengan kesatuan masyarakat adat. Namun, hingga saat naskah ini ditulis, tidak ada satupun undang-undang dari segi nomenklatur dan materi muatan yang secara khusus mengatur perihal masyarakat adat. ${ }^{1}$

Meski demikian, aktivitas-aktivitas warga negara yang berkaitan dengan kaidah "hukum adat", tetap berlangsung dan terpelihara. Hal ini karena hukum adat memiliki arah sama dengan hukum posisif Indonesia, yang berkaitan dengan keadilan, social order, serta mengusahakan upaya kebaikan bersama, sehingga dapat diterapkan di masyarakat berdampingan dengan jenis dan bentuk hukum lainnya. ${ }^{2}$ Hukum adat juga berfungsi sebagai institusi yang masih relevan dengan perkembangan hukum nasional, yang sebagiannya telah berbentuk kodifikasi serta menjadi sumber inspirasi bagi perkembangan hukum nasional. ${ }^{3}$

Salah satu eksistensi dari masyarakat hukum adat di Indonesia, yakni masyarakat adat suku Moi sebagai pemilik hak ulayat di Kota Sorong, Papua Barat. ${ }^{4}$ Kota Sorong Papua Barat merupakan salah satu daerah yang diberikan kewenangan otonomi khusus. ${ }^{5}$ Masyarakat adat

\footnotetext{
${ }^{1}$ Saat ini hanya terdapat RUU tentang Masyarakat Hukum Adat, namun belum disahkan menjadi undang-undang. Oleh sebab itu, selama ini pengaturan mengenai eksistensi masyarakat hukum adat hanya tersebar dalam beberapa peraturan perundang-undangan tanpa undang-undang secara khusus.

2 Arliman, L. (2018). Hukum Adat di Indonesia dalam Pandangan Para Ahli dan Konsep Pemberlakuannya di Indonesia. Jurnal Selat, 5(2), 177-190. DOI : https://doi.org/10.31629/selat.v5i2.320

3 Abubakar, L. (2013). Revitalisasi Hukum Adat Sebagai Sumber Hukum dalam Membangun Sistem Hukum Indonesia. Jurnal Dinamika Hukum, 13(2), 319-331. DOI: http://dx.doi.org/10.20884/1.jdh.2013.13.2.213

4 Suaib, Hermanto. (2017). Suku Moi: Nilai-Nilai Kearifan Lokal dan Modal Sosial dalam Pemberdayaan Masyarakat. Tangerang Selatan : An1mage, hlm. 58.

5 A. Sakti R.S. Rakia. (2021). Kewenangan Khusus Majelis Rakyat Papua Terhadap Pembentukan
} 
di kota sorong atau yang sering disebut masyarakat Adat Moi yang sangat menjunjung tinggi atas peraturan yang telah ada, dari zaman nenek moyang adat suku moi yang mereka percayai dan akan tetap berlaku selama masyarakatnya masih memenuhi hukum adat yang telah diwariskan. Dalam komunitas adat suku Moi, ditetapkan peraturan peraturan yang berkaitan dengan masalah pembayaran mas kawin, perzinahan, ataupun pembunuhan yang diterapkan oleh adat yang dianggap mengikat. ${ }^{6}$

Perkembangan penerapan hukum adat oleh banyak kalangan dikatakan cukup lambat dibandingkan dengan hukum lainnya untuk digunakan dalam menyelesaikan kasus-kasus konkrit. Salah satu penyebabnya dikarenakan bahwa adat masih bersifat tradisional sehingga kurang memiliki kemampuan untuk beradaptasi dengan kehidupan modern. ${ }^{7}$ Oleh sebab itu, opsi penerapan hukum adat kurang mendapat perhatian dibandingkan dengan jenis hukum lainnya. Hal ini juga pernah terjadi dalam sebuah kasus di kota sorong, dimana sebuah perkara adat yang telah diputuskan melalui adat, kemudian di bawa ke pengadilan umum untuk diselesaikan. ${ }^{8}$ Disisi lain, dalam pembangunan sistem hukum nasional, yang dimaksud dengan hukum positif Indonesia yakni hukum berbentuk perundang-undangan ataupun yurisprudensi, ${ }^{9}$ hukum agama, serta hukum adat. Artinya, wibawa hukum adat sama dengan wibawa hukum-hukum lainnya, sehingga seharusnya tidak boleh terjadi subordinasi antar satu sama lain.

Meski begitu, penerapan hukum adat, khususnya adat Moi di kota Sorong masih dilakukan oleh beberapa kalangan yang menganggap bahwa daya ikat hukum adat digunakan karena tidak hanya berkaitan dengan keadilan substantif, tetapi juga sebagai upaya dalam melestarikan eksistensi serta keberlangsungan hukum adat Moi. Dalam struktur adat Moi sendiri terdapat materi-materi hukum yang berkenaan dengan berbagai aspek, termasuk aspek pidana yang digunakan untuk mengadili perkara-perkara masyarakat. Secara konseptual, hal ini diistilahkan sebagai hukum adat delik (adatdelicten recht), atau dapat juga disebut "hukum pidana adat", atau "hukum pelanggaran adat", yakni, aturan-aturan hukum adat yang mengatur peristiwa atau perbuatan kesalahan yang berakibat pada terganggunya keseimbangan masyrakat. ${ }^{10}$

Dalam hal ini jika kita menganalisa dalam salah satu aliran sistem hukum dalam ilmu hukum yaitu Socioligical Jurisprudence yang disampaikan oleh Eugen Ehrlich yang mengkonseptualkan dari pemikiran Ehrlich tentang Ilmu Hukum yaitu apa yang dinamakan "Living Law". Hukum positif yang sedang berlaku pada suatu waktu tertentu dan tempat tertentu. merupakan hukum yang baik dan efektif dalam hukum yang sesuai dengan konsep Living Law dari masyarakat yang mencerminkan nilai nilai masyarakat yang hidup di dalamnya. Jika diperhatikan dalam kutipan Ehrlich tentang living law dalam kehidupan masyarakat adat Moi memiliki suatu kenyataan yang tidak dapat di pungkiri bahwa hukum

Perdasus. JUSTISI, 7(1), 14-25. DOI: https://doi.org/10.33506/js.v7i1.1168

${ }^{6}$ Mugu, D., Ali, M., \& Purwanti, N. (2019). Analisis Sistem Perkawinan Suku Moi Di Kabupaten Sorong. Jurnal Faksi: IImu Sosial dan IImu Politik, 4(2), 61-69.

7 Abubakar, L. (2013). Revitalisasi Hukum Adat... Op.cit.

${ }^{8}$ Kasus ini merupakan hasil pra-wawancara penulis dengan narasumber yang didaulat sebagai tetua adat suku MOI.

${ }^{9}$ Hukum berbentuk perundangan dan yurisprudensi sering diistilahkan sebagai hukum nasional.

${ }^{10}$ Hadikusuma, H. (2003). Pengantar Ilmu Hukum Adat Indonesia. Bandung: Mandar Maju, hlm. 230. 
adat yang berlaku di kota sorong khususnya masyarakat adat Moi.

Kaitannya dengan hal tersebut, maka dalam penelitian ini akan dilakukan pembedahan terhadap struktur hukum adat Moi, terutama mengenai hukum adat Moi yang berkaitan dengan tindak pidana. Dalam pada itu, penelitian ini mencoba untuk menjawab 2 (dua) pertanyaan, yaitu (i) Bagaimana Penegakan Hukum Terhadap Tindak Pidana Dengan Menggunakan Pendekatan Adat Moi di Kota Sorong; dan (ii) Apa yang menyebabkan Pendekatan Adat Moi menjadi bagian dalam Upaya Penegakan Hukum Tindak Pidana di Kota Sorong.

Metode yang digunakan dalam penelitian ini adalah jenis metode penelitian empiris yuridis. Teknik pengumpulan data dilakukan dengan cara melakukan studi lapangan (field reseach), yakni mewawancarai narasumber, survey, serta studi perbandingan hukum terbatas yang berkaitan dengan objek permasalahan yakni perihal tindak pidana dengan pendekatan hukum adat Moi. Selanjutnya, data yang diperoleh akan dianalisis secara kualitiatif untuk menghasilkan makna hukum, terutama yang berkaitan dengan masalah penyelesaian tindak pidana dengan pendekatan hukum adat MOI. Adapun lokasi penelitian yang ditentukan dalam penelitian ini adalah Polres kota Sorong, serta Lembaga Masyarakat Adat Moi (Malamoi) sesuai dengan kebutuhan objek penelitian.

\section{PEMBAHASAN}

\section{A. Konsep Hukum Adat}

Secara umum, hukum adat dipahami sebagai hukum yang hidup dalam suatu masyarakat hukum adat tertentu. Hukum adat merupakan aturan kebiasaan manusia dalam hidup berdampingan antar sesama masyarakat. Menurut A.A Fyzee, istilah hukum adat berasal dari kata arab, yakni "huk'm" (jamak: ahkam), yang berarti sebuah "suruhan" atau ketentuan. Sedangkan "adah" atau adat artinya adalah kebiasaan, yakni perilaku masyarakat yang selalu terjadi. ${ }^{11}$ Rangkaian evolusi hukum adat dimulai dari akal atau pikiran manusia sebagai sarana berpikir yang diberikan oleh Tuhan, yang diwujudkan dalam perilaku. Apabila perilaku ini ditiru oleh orang lain, maka akan lahir suatu kebiasaan. Ketika kebiasaan tersebut diakui oleh banyak orang, selanjutnya kebiasaan tersebut menjadi adat, serta dalam tingkat pemerintahan maka disebut sebagai hukum adat. Adapun rangkaian tersebut, oleh Hilman Hadikusuma digambarkan sebagai berikut $:^{12}$

Gambar 1. Diagram Evolusi Hukum Adat

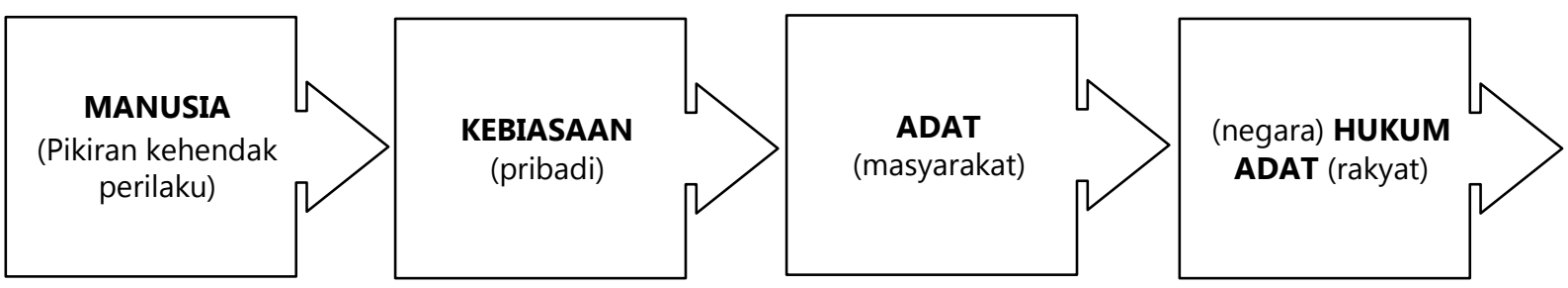

Dalam literatur klasik, Bushar Muhammad menguraikan hukum adat adalah sebagai berikut :

\footnotetext{
${ }^{11}$ Hadikusuma, H. (2003). Ibid.

${ }^{12}$ Ibid.
} 
Istilah "hukum adat" adalah terdjemahan dari istilah dalam bahasa Belanda, yakni "adatrecht". Snouck Hurgronje adalah orang paling pertama jang memakai istilah "adatrecht" itu. Istilah "adatrecht" kemudian dikutip dan dipakai untuk selandjutnja oleh van Vollenhoven. Sebelumnja, hukum adat itu dinjatakan dengan dipakainja berbagai kata-kata, seperti perundang-undangan, yaitu "godsdienstige wetten, volksinstellingen en gebruiken", atau "godsdienstige wetten, instellingen en gebruiken". Dalam perundang-undangan, istilah, "adatrecht" itu baru muntjul pada tahun 1920, jaitu untuk kali pertama dipakai dalam undang-undang Belanda mengenai perguruan tinggi di Negeri Belanda, Ned (erlands) Stbl. 1920 nr 105 dan dalam Academisch Statuut. ${ }^{13}$

Sebenarnya ada perbedaan mendasar berkaitan dengan istilah "hukum adat" dan "hukum kebiasaan". Dikalangan masyarakat umum, istilah hukum adat sebenarnya jarang digunakan, tetapi yang banyak dipakai adalah isitilah "adat", misalnya untuk menyebut adat jawa, adat bugis, adat batak. Kata "adat" ini juga sama maknanya dengan "kebiasaan". ${ }^{14} \mathrm{Hal}$ ini sesuai dengan apa yang diuraikan oleh Achmad Ali yang menyebutkan bahwa sebenarnya yang dikenal dalam kehidupan bangsa Indonesia hanya "adat", bukan "hukum adat". ${ }^{15}$ Lebih lanjut secara tegas Achmad Ali mengatakan bahwa, istilah "hukum adat" harus segera ditinggalkan karena tidak sesuai dengan realitas masyarakat Indonesia, oleh karena ciri khas dari hukum adat itu sendiri yang bersifat tradisional.

Adat atau kebiasaan merupakan tingkah laku yang dilakukan terus menerus dengan cara-cara tertentu serta diikuti atau ditiru oleh masyarakat dalam waktu yang relatif lama. Oleh sebab itu, menurut Yulia, unsur-unsur adat adalah :
a. Adanya tingkah laku seseorang;
b. Dilakukan terus menerus;
c. Adanya dimensi waktu; dan
d. Diikuti oleh orang lain. ${ }^{16}$

Selanjutnya, disebutkan bahwa ciri-ciri hukum adat yaitu :

a. Tidak tertulis dalam bentuk perundangan dan tidak dikodifikasi;

b. Tidak tersusun secara sistematis;

c. Tidak dihimpun dalam bentuk kitab perundangan;

d. Tidak teratur;

e. Keputusannya tidak memakai konsideran (pertimbangan); dan

f. Pasal-pasal aturannya tidak sistematis dan tidak mempunyai penjelasan. ${ }^{17}$

Dalam pada itu, menurut Achmad Ali, ciri-ciri khas adat adalah sebagai berikut:

\footnotetext{
${ }^{13}$ Bushar, Muhammad. (1961). Pengantar Hukum Adat. Djakarta : Penerbit dan balai Buku "Ichtiar", hlm. 12.

${ }^{14}$ Hadikusuma, H. (2003). Op.cit.

${ }^{15}$ Ali, Achmad. (2002). Menguak Tabir Hukum : Suatu kajian Filosofis dan Sosiologis. Jakarta : PT. Toko Gunung Agung, hlm 115.

${ }^{16}$ Yulia. (2016). Buku Ajar Hukum Adat. Lhokseumawe : Unimal Press, hlm. 1.

${ }^{17}$ Ibid.
} 

a. Konkret;
b. Magis religius;
c. Kontan; dan
d. Lokal. $^{18}$

Adat istiadat membentuk sikap, tindakan atau perubahan manusia pada masyarakat hukum adat, yang selanjutnya mempertahankan adat istiadat tersebut dan berlaku di lingkungan wilayah tertentu. Terkadang, adat istiadat dipertahankan oleh karena kesadaran masyarakatnya, namun dapat pula adat istiadat dipertahankan karena sanksi ataupun akibat hukum tertentu sehingga menjadi hukum adat.

Hukum adat terdiri dari beberapa bidang. Beberapa pembidangan oleh para ahli dijelaskan dalam tabel sebagai berikut:

Tabel 1. Pembidangan Hukum Adat

\begin{tabular}{|c|c|}
\hline Nama Tokoh & Jenis Pembidangan \\
\hline Van Vollen Hoven & $\begin{array}{l}\text { 1. Bentuk-Bentuk Masyarakat Hukum Adat; 2. Tentang Pribadi; } 3 . \\
\text { Pemerintahan Dan Peradilan; 4. Hukum Keluarga; 5. Hukum Perkawinan; } \\
\text { 6. Hukum Waris; 7. Hukum Tanah; 8. Hukum Hutang Piutang; 9. Hukum } \\
\text { Delik ; 10. Sistem Sanksi. }{ }^{19}\end{array}$ \\
\hline Soepomo & $\begin{array}{l}\text { 1. Hukum Keluarga; 2. Hukum Perkawinan; 3. Hukum Waris; 4. Hukum } \\
\text { Tanah; } 5 \text {. Hukum Hutang Piutang; } 6 \text {. Hukum Pelanggaran. }{ }^{20}\end{array}$ \\
\hline Ter Harr & $\begin{array}{l}\text { 1. Tata Masyarakat; 2. Hak-Hak Atas Tanah; 3. Transaksi-Transaksi Tanah; } \\
\text { 4. Transaksi-Transaksi Dimana Tanah Tersangkut; 5. Hukum Hutang } \\
\text { Piutang; 6. Lembaga/ Yayasan; 7. Hukum Pribadi; 8. Hukum Keluarga; } 9 . \\
\text { Hukum Perkawinan; 10. Hukum Delik; 11. Pengaruh Lampau Waktu. }{ }^{21}\end{array}$ \\
\hline Surojo Wignjodipuro & $\begin{array}{l}\text { 1. Tata Susunan Rakyat Indonesia; } 2 \text {. Hukum Perseorangan; 3. Hukum } \\
\text { Kekeluargaan; 4. Hukum Perkawinan; } 5 \text {. Hukum Harta Perkawinan; } 6 . \\
\text { Hukum (Adat) Waris; 7. Hukum Tanah; } 8 \text {. Hukum Hutang Piutang; } 9 . \\
\text { Hukum (Adat) Delik. }{ }^{22}\end{array}$ \\
\hline Hilman Hadikusuma & $\begin{array}{l}\text { 1. Hukum Adat Ketatanegaraan; } 2 \text {. Hukum Adat Perkawinan; 3. Hukum } \\
\text { Adat Kekerabatan; 4. Hukum Adat Waris; } 5 \text {. Hukum Adat Perekonomian; } \\
\text { 6. Hukum Adat Delik; } 7 \text {. Hukum Adat Peradilan. }{ }^{23}\end{array}$ \\
\hline
\end{tabular}

\footnotetext{
${ }^{18}$ Ali, Achmad. (2002). Menguak Tabir Hukum, Op.cit.

${ }^{19}$ Ragawino, Bewa. Pengantar dan Asas-Asas Hukum Adat Indonesia. Bandung : Fakultas Ilmu Sosial Dan Ilmu Politik Universitas Padjadjaran, hlm 16.

${ }^{20}$ Ibid.

${ }^{21}$ Ibid

22 Ibid

${ }^{23}$ Hadikusuma, H. (2003). Op.cit.
} 


\section{B. Pidana dan Delik Adat}

Dalam kaidah adat juga dikenal struktur aturan adat yang berkaitan dengan aspek pidana, yakni merupakan aturan yang mengatur peristiwa atau perbuatan kesalahan yang berakibat pada terganggunya keseimbangan masyarakat sehingga perlu dibebankan hukuman kepada pelaku. Aspek pidana dalam adat, isitlah yang digunakan adalah adatdelicten recht atau delik adat, yang oleh Van Vollen Hoven diuraikan sebagai suatu perbuatan yang dilarang atau tidak boleh dilakukan, meskipun perbuatan itu hanya sumbang, atau kesalahan kecil. ${ }^{24}$

Menurut Teer Haar, suatu delik itu sebagai tiap-tiap gangguan dari keseimbangan, tiap-tiap gangguan pada barang-barang materiil dan immaterial milik hidup seorang atau kesatuan orang-orang yang menyebabkan timbulnya suatu reaksi adat, yang dengan reaksi ini keseimbangan akan dan harus dapat dipulihkan kembali. ${ }^{25}$ Sedangkan menurut Soepomo, delik adat adalah segala perbuatan atau kejadian yang sangat menggangu kekuatan batin masyarakat. Segala perbuatan atau kejadian yang mencemarkan suasana batin dan merusak kesucian masyarakat merupakan delik terhadap masyarakat seluruhnya. ${ }^{26}$

Adapun mengenai sifat dari delik adat, oleh Hilman Hadikusuma diuraikan sebagai berikut:

a. Tradisional magis, yakni perbuatan yang tidak boleh dilakukan. Apabila larangan ini dilanggar, maka bukan saja keluarga, masyarakat akan terganggu juga keseimbangannya, akan tetapi juga mendapat kutukan dari yang ghaib.

b. Menyeluruh dan menyatukan, yakni tidak memisahkan antara delik yang bersifat pidana atau bersifat perdata.

c. Tidak praes-existente, yakni tidak seperti hukum pidana barat sebagaimana dinyatakan dalam KUHP.

d. Tidak menyamaratakan, yakni dengan memperhatikan antara reaksi dan koreksi atas delik yang terjadi. Jika delik dilakukan oleh orang yang bermartabat, maka hukumannya akan lebih berat.

e. Terbuka dan lentur, yakni senantiasa terbuka terhadap unsur-unsur yang baru, yang berubah. Adat tidak menolak perubahan sepanjang tidak bertentangan dengan kesadaran hukum dan keagamaan masyarakat.

f. Terjadinya delik adat, yakni apabila tata tertib adat setempat dilanggar, atau karena suatu pihak menderita kerugian oleh pihak lain.

g. Delik aduan, yakni terjadinya suatu delik yang berakibat mengganggu keseimbangan maka untuk menyelesaikan tuntutan atau gugatan dari pihak yang

\footnotetext{
${ }^{24}$ Ibid.

${ }^{25}$ Ragawino, Bewa. Pengantar dan Asas-Asas Hukum Adat Indonesia, Loc.cit.

${ }^{26}$ Yulia. (2016). Buku Ajar Hukum Adat, Loc.cit.
} 
dirugikan melalui pengaduan, harus disertai pemberitahuan dan permintaan kepada tetua atau kepala adat.

h. Reaksi dan koreksi, yakni untuk dapat memulihkan kembali keseimbangan masyarakat yang terganggu.

i. Pertanggungjwaban kesalahan, yakni berkaitan dengan suatu delik adat yang mempermasalahkan "akibat" dari perbuatan tersebut serta sipa atau pihak mana yang diminta pertanggungjawaban.

j. Keberlakukan, yakni tidak berlaku secara nasional. ${ }^{27}$

Selain itu, terdapat pula macam-macam delik adat, yaitu yang terdiri dari kesalahan mengganggu ketertiban dan keamanan, dapat diuraikan sebagai berikut :

a. Kesalahan mengganggu keamanan. Misalnya kebakaran, perampokan dan kerusuhan, pembunuhan, pertikaian, penganiayaan, pencurian, menemukan barang.

b. Kesalahan mengganggu ketertiban. Misalnya kesalahan tata tertib masyarakat, tata tertib pemerintahan, kesopanan dan kesusilaan, kesalahan dalam perjanjian, kesalahan menyangkut tanah serta tanaman dan hasil hutan, kesalahan menyangkut hewan ternak. ${ }^{28}$

\section{Tinjauan Umum Mengenai Adat MOI}

\section{Sejarah Suku Moi di Wilayah Sorong, Papua Barat}

Suku Moi merupakan suku asli yang mendiami wilayah Kota dan Kabupaten Sorong dan kabupaten Raja Ampat. Istilah Moi atau Mosana bermakna "orang yang lembut dan ramah", yakni menggambarkan orang-orang di bagian pulau Salawati yang menghadap pada tanjung kepala burung. Istilah mosana sebenarnya ditujukan untuk suku Moi secara menyeluruh meskipun hal tersebut tidak berlaku menyeluruh. ${ }^{29}$

Sorong dalam bahasa suku Moi disebut engan maladum oleh karena saat daerah ini dibuka, pemerintahan Belanda memperkerjakan penduduk pulau ini, yakni suku Moi, untuk membersihkan lahan yang dipenuhi oleh tumbuhan gelobak (sejenis lengkuas), yang dalam bahasa Moi disebut dum. Oleh karena itu, suku Moi menamakan wilayah sorong dengan sebutan $d u m$, yakni lahan yang banyak tumbuhan $d u m .{ }^{30}$ Suku Moi sendiri merupakan suku asli yang ada di wilayah ini, suku Moi menyebut daerah tempat mereka tinggal dengan sebutan maladum. Kata Moi merupakan istilah untuk masyarakat dengan karakteristik yang lembut, sopan, tidak beringas, dan bertutur kata manis. Suku Moi tidak memiliki tulisan sebagai bukti yang dapat menunjukkan identitas asal muasal suku Moi sendiri. ${ }^{31}$

\footnotetext{
${ }^{27}$ Hadikusuma, H. (2003). Loc. cit.

${ }^{28}$ Ibid.

${ }^{29}$ Malak, Stevanus, \& Likewati, W. (2011). Etnografi Suku Moi. Bogor : PT Sarana Komunikasi Utama, hlm. 24.

${ }^{30}$ Suaib, Hermanto. (2017). Suku Moi...Loc.cit.

${ }^{31}$ Yunita, F. E. (2018). Pelepasan Hak Atas Tanah Adat Menjadi Hak Milik Perorangan Pada Suku Moi Di Kabupaten Sorong Provinsi Papua Barat. Tesis. Program Magister Kenotariatan Program Pascasarjana Fakultas Hukum Universitas Islam Indonesia, hlm. 60
} 
Seiring perkembangannya, belakangan terdapat suku pendatang yang diistilahkan ne saf sehingga menghasilkan adanya percampuran budaya, termasuk karakter asli dari suku Moi yang diistilahkan dengan neulig, yakni seseorang yang diakui dalam adat istiadat budaya suku Moi adalah seorang tuan tanah, yang telah mendiami tanah di lingkungannya untuk pertama kali. Oleh sebab itu maka terjadilah perkawinan campuran, serta membentuk marga baru dalam suku Moi yang terdiri dari marga besar dan marga kecil yang disebut gelet. $^{32}$

\section{Pembagian Sub-Suku dan Marga Suku Moi}

Adat suku Moi pada dasarnya terbagi menjadi beberapa sub-suku dan marga dengan wilayah masing-masing, yang terdiri dari suku besar dan suku kecil. Dalam proses indentifikasi sub-suku dan marga suku Moi, terdapat perbedaan dari segi referensi. Misalnya, disebutkan bahwa sub-suku/etnik Moi terdiri dari Moi legin, Moi abun, Moi karon, Moi klabra, Moi moraid, Moi segin, dan Moi maya. ${ }^{33}$ Sumber lain menyebutkan bahwa suku Moi yang terdiri atas 12 rumpun suku Moi besar antara lain, yakni Moi Kilin, Moi Sigali (Moi Mare), Moi Maya, Moi Klasa, Moi Moraid, Moi Seget, Moi Klabra, Moi Madik, Moi Karon, Moi Meiyakh, Moi Batan Mee/Batbat, dan Moi Fiyawat. ${ }^{34}$

Referensi yang menyertakan sub-suku/etnik yang cukup lengkap, dapat diuraikan dalam tabel sebagai berikut : ${ }^{35}$

Tabel 2. Daftar Suku dan Marga Moi

\begin{tabular}{|c|c|}
\hline Suku Moi & Marga \\
\hline Moi Kalasa & $\begin{array}{l}\text { Bisulu, Do, Gifelem, Lagu, Malawok, Malak, Malasumuk, Mulu, Pa, } \\
\text { Salamala, Sani, Sawisa, Siwele, Ulim kalapoto, Ulimpa. }\end{array}$ \\
\hline Moi Kalagedi & $\begin{array}{l}\text { Kadakolo, Kalami, Kalasuat, Kalawin, Magablo, Mainolo, Mobalen, } \\
\text { Mobilala, Ulim, Wali, Idik. }\end{array}$ \\
\hline Moi Malaimsimsa & Bewela, Sani, Kalagison, Malabalus, Malasalim. \\
\hline Moi Amber & Kalaibin, Kalaluk, Kalawi, Malaseme, Malibela, Mili, Osok \\
\hline Moi Malayik & $\begin{array}{l}\text { Bisi, Kalawaisa, Kalawen, Komala, Semugu, Aksili, Malagili, Maga, } \\
\text { Malagam, Mamerni. }\end{array}$ \\
\hline Moi Seget & $\begin{array}{l}\text { Fedan, Felis, Fes, Funus, Gisim, Trik, Kalawom, Kami, Malakubu, Malalu, } \\
\text { Sawak, Simi. }\end{array}$ \\
\hline Moi Kelim & $\begin{array}{l}\text { Fami, Gilik, Kalalu, Kalasibin, Kalamali, Kilala, Komigi, Kwaktolo, Samolo, } \\
\text { Su, U, Siwele }\end{array}$ \\
\hline \multirow{3}{*}{\multicolumn{2}{|c|}{$\begin{array}{l}32 \text { Ibid. } \\
{ }^{33} \text { Suaib, Hermanto. (2017). Suku Moi...Loc.cit. } \\
{ }^{34} \text { Suroto, H. (16 Januari 2020). Lebih Dekat Dengan Suku Moi Dari Sorong. Diakses pada } 14 \text { Juli } 2021 \text { dari : } \\
\text { https://www.nabire.net/lebih-dekat-dengan-suku-moi-dari-sorong/ } \\
{ }^{35} \text { Yunita, F. E. (2018). Pelepasan Hak Atas Tanah Adat...Op.cit. }\end{array}$}} \\
\hline & \\
\hline & \\
\hline & JUSTISI | UNIVERSITAS MUHAMMADIYAH SORONG 48 \\
\hline
\end{tabular}




\section{Moi Walala}

Moi Abun

Moi Malaibin
Asrima, Balinsa, Dan, Galus, Keling, Ligik, Madewe, Malagifik, Malawanutu, Mingginsubu, Minggintuak, Metla, Sekamuk, Sipolo, Tuwen, Ulala, Ulimene, Urini, Yempolo, Supukala, Patele.

Suwalik, Mialim, Faam, Kibiy, Tiplu.

Sementara itu, berdasarkan penelusuran yang penulis lakukan bersama tim di Sorong, Papua Barat, Beberapa marga yang terdapat di dalam suku Moi ada 21 (dua puluh satu) marga, yaitu, marga Ulim, Ulimpa, Osok, Malibela, Bawela, Mobilala, Mobalen, Mainolo, Magablo, Sani, Gifelem, Do, Malak, Kalasuat, Kamuru, Kalaibin, Komili, Su, Kadokolo, Kwatolo, Kalami.

\section{Persebaran Suku Moi}

Berdasarkan catatan Pdt. E. Osok yang dibenarkan oleh saksi sejarah Sangaji Warwei, suku Moi pertama kali mengenal dan keluar hutan dan bertemu dengan suku Biak dengan marga Warwei, Warfandu, dan Mansawer yang sudah mendiami wilayah suku Moi. Ketiga marga ini mendiami hulu hingga hilir sungai Mariat sebelum ditempatkan oleh Raja suku Moi Fun Najam dan Nagerim ke Pulau Doom. ${ }^{36}$

Disebutkan bahwa 12 rumpun Moi besar, yakni Moi Kilin, Moi Sigali (Moi Mare), Moi Maya, Moi Klasa, Moi Moraid, Moi Seget, Moi Klabra, Moi Madik, Moi Karon, Moi Meiyakh, Moi Batan Mee/Batbat, dan Moi Fiyawat, bermukim Suku Moi ini bermukim di tepi pantai, daratan rendah dan muara sungai. ${ }^{37}$ Sumber lain menyebutkan beberapa suku atau marga suku Moi, terdiri dari suku Klabra, Karon, Madik, Kebar, Keboro, dan Yaun, yang tersebar di Distrik Feet, Abun, Sausafor, Moraid, Makbon, Aimas, Salawati, Seget, Segun, Beraur, Klamono, dan Disrik Sayosa. ${ }^{38}$ Sekarang ini sebagian besar suku Moi mendiami atau bertempat tinggal di beberapa kampung, yakni kampung malaumkarta yang terbagi menjadi 3 (tiga) kampung yaitu kampung Kwadas, kampung Klaluk, dan kampung Malaumkarta, distrik makbon dan Kabupaten Sorong, Provinsi Papua Barat. ${ }^{39}$

\section{Penyelesaian Masalah dalam Adat Moi}

Kehidupan masyarakat suku Moi dilandasi kepercayaan bahwa tempat tinggal mereka telah ditentukan oleh nenek moyang berdasarkan batas-batas alam. Masyarakat suku Moi hidup bertalian satu sama lain sesuai tanah yang didiami. Hubungan ini kemudian memunculkan sejumlah hak-hak, misalnya hak-hak peralihan atas tanah atau yang disebut

\footnotetext{
${ }^{36}$ Suaib, Hermanto. (2017). Suku Moi...Loc.cit.

37 Yapsenang, Y. N., \& Usmany, D.P. (2019). Mekanisme Penyelesaian Konflik Tradisional Suku Bangsa Moi (Traditional Solution of Conflict in Moi Tribe). Jurnal Penelitian Arkeologi Papua Dan Papua Barat, 11(1), 57-69. https://doi.org/10.24832/papua.v11i1.266

${ }^{38}$ Dikutip dari dokumen Bab II RPIJM Kabupaten Sorong. Tidak diterbitkan.

${ }^{39}$ KKP.go.id. (03 Mei 2019). Egek (Sasi), Kearifan Lokal Suku Moi Perembahan Suku Moi Kelim Untuk Konservasi Perairan Yang Berkelanjutan. Diakses pada 14 Juli 2021 dari : https://kkp.go.id/djprl/lpsplsorong/artikel/10387egek-sasi-kearifan-lokal-suku-moi-perembahan-suku-moi-kelim-untuk-konservasi-perairan-yang-berkelanjutan
} 
dengan hak tegestemoi, yakni hak yang diturunkan secara turun temurun. ${ }^{40}$ Contoh dari hakhak tegestemoi berupa :

a. Hak egefmun, yakni merupakan hak milik yang biasanya diperoleh dari keturunan darah.

b. Hak subey, yakni hak pakai yang diberikan kepada seorang anak susuan untuk dipakai tapi tidak dimiliki.

c. Hak sukubang, yakni hak pemberian tanah kepada anak perempuan sebagai tempat berladang. Hak ini berfungsi manakala anak tersebut menetap, namun jika tidak menetap, maka tanahnya dikembalikan.

d. Hak woti, yakni hak pemberian tanah kepada orang yang telah membantu/ melindungi dalam perang (balas jasa).

e. Hak somala, yakni penyerahan hak ulayat kepada orang luar karena wilayah tersebut dianggap tidak aman. ${ }^{41}$

Dalam menyelesaikan suatu masalah atau konflik, dahulu suku Moi dalam menyelesaikan permasalahan dalam kehidupan sosial, memiliki suatu mekanisme tersendiri yang diistilahkan dengan teh bless dan kalak foo. ${ }^{42}$ Teh bless adalah suatu mekanisme penyelesaian konflik dalam perselingkuhan, pencurian, dan masalah yang seringkali terjadi di suku Moi. Terhadap permasalahan tersebut, tetua adat akan melakukan rapat dengan pihakpihak yang bertikai, untuk menentukan mekanisme penyelesaian konflik, lokasi, serta waktu dan besaran pembayaran.

Sedangkan kalak foo tidak diketahui secara pasti kapan bermulanya, namun kalak foo digunakan sebagai sarana untuk menjawab permasalahan-permasalahan yang terjadi, serta dapat juga digunakan untuk menjawab pertanyaan dalam diri masyarakat pada saat itu. ${ }^{43}$ Baik teh bless dan kalak foo diperoleh secara tidak sengaja melalui "orang tua" dari alam, atas pertanyaan mengenai mekanisme yang dapat digunakan dalam menyelesaikan permasalahan antar suku bangsa Moi. $^{44}$

\section{Penyelesaian Tindak Pidana Berdasarkan Hukum Adat Moi}

1. Penegakan Hukum Terhadap Tindak Pidana dengan Menggunakan Pendekatan Hukum Adat Moi

Masyarakat Moi sangat menjunjung tinggi adat istiadat sehingga mereka menganggap hukum adat itu sebagai pedoman hidup mereka, dan mereka sangat lekat dengan adat sehingga adat istiadat itu tidak bisa dihilangkan (turun temurun) dan sudah menjadi ketentuan adat. Masyarakat yang melanggar ketentuan adat akan dikenakan sanksi-saknsi atau denda tertentu sesuai dengan kejahatan atau pelanggaran yang dilakukan.

\footnotetext{
${ }^{40}$ Suroto, H. (16 Januari 2020). Lebih Dekat Dengan Suku Moi Dari Sorong... Loc.cit.

41 Ibid.

${ }^{42}$ Yapsenang, Y. N., \& Usmany, D.P. (2019). Mekanisme Penyelesaian... Loc.cit.

43 Ibid.

${ }^{4}$ Ibid.
} 
Meski begitu, penerapan sanksi pidana dikota sorong harus didahului dengan penyelesaian adat terdahulu dikarenakan pada kasus-kasus pidana untuk penyelesaian litigasi ataupun non-litigasi akan adanya tinjauan terhadap masyarakat adat atau kepala adat Moi sebagai pemangku tinjauan adat. Dalam pada itu, hukum adat Moi yang berlaku bisa menjadi subsidair atau sebagai pengganti hal pokok apabila hal pokok tidak terjadi seperti hukuman denda sebagai pengganti hukuman kurungan, apabila pelaku tidak menjalankan hukuman kurungannya.

Contoh sanksi atau denda adat Moi terhadap kejahatan atau pelanggaran, yakni membayar denda berupa :

a. Piring gantung sebagai barang adat dalam jumlah yang ditentukan.

b. Guci sebagai barang adat dalam jumlah yang ditentukan.

c. Kain Melteba sebagai barang adat dalam jumlah yang ditentukan.

d. Babi sebagai bentuk upacara dalam melakukan kegiatan adat dalam jumlah yang ditentukan.

e. Sejumlah uang tunai yang ditentukan.

Untuk jumlah denda hukuman adat ditentukan oleh korban atau orang yang merasa dirugikan dan kepala adat Moi. Setelah hukum adat telah tercapai dan terlaksanakan maka untuk pencapaian proses selanjutnya dalam perihal kasus-kasus pidana akan berlangsung sesuai dengan hukum nasional yang berlaku. Dan ketika melanjutkan kasus pidana ke tahap pengadilan, hasil dari penyelesaian hukum adat dapat menjadi tolak ukur atau pertimbangan dalam keputusan pengadilan jika diselesaikan dengan metode litigasi.

Upaya dalam penyelesaian kasus-kasus pidana dengan menggunakan metode pendekatan adat di kota Sorong, Polres Sorong Kota sebagai wadah atau tempat bagi masyarakat untuk melaporkan tindak kejahatan atau kriminalitas yang terjadi di kota Sorong bekerjasama dengan masyarakat Adat setempat khususnya masyarakat Adat Moi. Dalam menyelesaikan perkara pidana ringan, Polres Sorong Kota menggunakan mekanisme bekerja sama aparat Kepolisian polres Sorong kota dengan Masyarakat Adat yang bersangkutan atau yang berperkara ( Lembaga adat), mulai dari adanya menerima laporan, memanggil para pihak, saksi, melakukan musyawarah, sampai kemudian kepada pengambilan keputusan oleh pimpinan lembaga adat atau masyarakat Adat yang bersangkutan.

Polres Sorong kota berdiri sebagai fasilitator menyediakan tempat guna masyarakat adat dari kedua belah pihak melakukan musyawarah, kedua masyarakat adat, baik dari pihak masyarakat adat yang menjadi korban maupun dari pihak masyarakat adat yang menjadi pelaku kasus pidana tersebut. Dalam pengamatan langsung yang dilakukan terhadap proses penyelesaian tersebut, kedua belah pihak berkumpul dalam satu tempat atau ruangan yang telah di sediakan kepolisian polres Sorong kota agar kedua belah pihak dari masyarakat adat dapat bermusyawarah mencari titik temu atau keputusan dalam menyelesaikan kasus pidana tersebut.

Biasanya dilakukan proses mediasi yang berkaitan dengan perihal ganti ruginya secara materil atau sejumlah uang yang di minta oleh masyarakat adat yang menjadi korban. 
Masyarakat adat yang menjadi pelaku dalam kasus pidana tersebut wajib membayar ganti rugi sejumlah uang yang telah di tentukan. Setelah adanya pembayaran dari pihak korban maka kasus pidana tersebut dianggap telah selesai dan masyarakat adat yang menjadi korban dalam kasus pidana tersebut menarik laporan dari kepolisian polres Sorong kota.

\section{Penyebab Pendekatan Hukum Adat Moi dalam Upaya Penegakan Hukum Tindak Pidana}

Pelanggaran terhadap hukum pidana memiliki konsekuensi harus diadili oleh negara. Tetapi di Kota Sorong, masyarakat adat Moi cenderung lebih memilih untuk mengesampingkan penyelesaian dengan sistem peradilan pidana nasional dan lebih memilih penyelesaian di luar pengadilan termasuk dengan mekanisme hukum adat. Dalam penegakan hukum dengan mengunakan metode pendekatan adat Moi, ada kecenderungan untuk mengedepankan asas kekeluargaan menggunakan musyawarah untuk mengambil keputusan yang telah di sepakati kedua belah pihak yang berperkara baik dari pihak korban maupun dari pihak pelaku.

Kota Sorong sebagai daerah dimana masyarakat adat sangat di hormati dan berperan aktif dalam mengambil keputusan dalam semua masalah yang ada di kota tersebut. Sehingga keputusan yang telah di putuskan oleh masyarakat adat menjadi representasi masyarakat secara keseluruhan yang ada di kota Sorong. Lembaga adat (Masyarakat Adat) yang menjatuhkan pidana adat itu diakui dalam sistem peradilan Indonesia, sehingga bila sebuah kasus selesai di lembaga adat, maka kasus itu sudah dianggap selesai.

Dalam proses wawancara yang dilakukan berkaitan dengan penyebab serta tujuan dari pelaksanaan proses adat dalam menyelesaikan perkara, dikatakan bahwa masyarakat Moi menganggap hukum adat sebagai pedoman hidup. Jadi masyarakat suku Moi tidak dapat terlepas dengan hukum adat sebagai pedoman kehidupan suku Moi. Dari segi kepuasan, berdasarkan keterangan dari suku adat Moi, pada dasarnya masyarakat adat cukup puas, selama proses hukum adatnya tetap berjalan sesuai dengan permintaan denda adat yang diminta oleh pihak korban karena telah melanggar norma budaya mereka. Dari segi manfaat, dikatakan bahwa manfaat yang diperoleh dari penyelesaian masalah dengan menggunakan adat sangat jelas dirasakan manfaatnya karena dengan menggunakan hukum adat lebih memberikan efek jera terhadap pelaku dan rasa keadilan terhadap pihak korban.

Terkait dengan penerapan sanksi atau denda adat Moi, pelaksanaan prosesi adat terhadap suku yang berbeda marga pada dasarnya sama, yakni dikenakan denda adat sesuai yang di minta dari pihak korban. Kepala suku adat akan mempertemukan kedua pihak untuk mendamaikan. Cara perdamaian itulah yang kerap di sebut denda adat berupa uang, piring gantung, guci, kain melteba (kain kepala) dan beberapa ekor babi. Biasanya babi yang di dapatkan dari pihak pelaku akan di potong ,di masak dan di makan bersama sama dengan keluarga terdekat, akan tetapi hasil masakan yang di makan bersama tidak boleh di nikmati oleh pihak pelaku.

\section{KESIMPULAN}

Penegakkan tindak pidana melalui adat Moi pada dasarnya dipengaruhi oleh penghormatan masyarakat adat Moi yang sangat menjunjung tinggi adat istiadat itu 
pedoman hidup. Adat isitiadat suku Moi mereka sangat lekat dengan masyarakat suku Moi, dan telah berlangsung secara turun temurun sebagai ketentuan adat. Hal ini menyebabkan beberapa kasus yang meski telah ditangani oleh kepolisian, namun tetap saja proses pelaksanaannya dengan memerhatikan ketentuan adat yang berlaku. Adapun penyebab dari penggunaan adat sebagai sarana penyelesaian masalah di suku Moi karena dirasakan lebih sesuai dengan makna adil dalam suasana kebatinan masyarakat suku Moi, serta lebih memberikan efek jera pada pelaku. Hal ini tidak hanya berkaitan dengan pembebanan hukuman, tetapi juga berkaitan dengan hukuman ghaib yang dipercaya akan dihadapi oleh pelaku.

\section{ACKNOWLEDGEMENT}

Terima kasih kepada Kemendikbud Ristek yang telah menyelenggarakan program hibah Center of Exellent (CoE) Merdeka Belajar Kampus Merdeka, dalam hal pembiayaan terkait dengan program penelitian/riset kolaborasi mahasiswa dan dosen pada Fakultas Hukum Universitas Muhammadiyah Sorong.

\section{REFERENSI}

Abubakar, L. (2013). Revitalisasi Hukum Adat Sebagai Sumber Hukum dalam Membangun Sistem Hukum Indonesia. Jurnal Dinamika Hukum, 13(2), 319-331. DOI: $\underline{\text { http://dx.doi.org/10.20884/1.jdh.2013.13.2.213 }}$

Ali, Achmad. (2002). Menguak Tabir Hukum: Suatu kajian Filosofis dan Sosiologis. Jakarta: PT. Toko Gunung Agung

Arliman, L. (2018). Hukum Adat di Indonesia dalam Pandangan Para Ahli dan Konsep Pemberlakuannya di Indonesia. Jurnal Selat, 5(2), 177-190. DOI: https://doi.org/10.31629/selat.v5i2.320

Bushar, Muhammad. (1961). Pengantar Hukum Adat. Djakarta: Penerbit dan balai Buku "Ichtiar".

Dokumen Bab II RPIJM Kabupaten Sorong. Tidak diterbitkan.

Hadikusuma, H. (2003). Pengantar Ilmu Hukum Adat Indonesia. Bandung: Mandar Maju.

KKP.go.id. (03 Mei 2019). Egek (Sasi), Kearifan Lokal Suku Moi Perembahan Suku Moi Kelim Untuk Konservasi Perairan Yang Berkelanjutan. Diakses pada 14 Juli 2021 dari: https://kkp.go.id/djprl/lpsplsorong/artikel/10387-egek-sasi-kearifanlokal-suku-moi-perembahan-suku-moi-kelim-untuk-konservasi-perairanyang-berkelanjutan

Malak, Stevanus, \& Likewati, W. (2011). Etnografi Suku Moi. Bogor: PT Sarana Komunikasi Utama.

Mugu, D., Ali, M., \& Purwanti, N. (2019). Analisis Sistem Perkawinan Suku Moi Di Kabupaten Sorong. Jurnal Faksi: Ilmu Sosial dan Ilmu Politik, 4(2), 61-69. 
Ragawino, Bewa. Pengantar dan Asas-Asas Hukum Adat Indonesia. Bandung: Fakultas Ilmu Sosial Dan Ilmu Politik Universitas Padjadjaran.

Rakia, A. Sakti R.S. (2021). Kewenangan Khusus Majelis Rakyat Papua Terhadap Pembentukan Perdasus. JUSTISI, 7(1), 14-25. DOI: https://doi.org/10.33506/js.v7i1.1168

Suaib, Hermanto. (2017). Suku Moi: Nilai-Nilai Kearifan Lokal dan Modal Sosial dalam Pemberdayaan Masyarakat. Tangerang Selatan : An1mage.

Suroto, H. (16 Januari 2020). Lebih Dekat Dengan Suku Moi Dari Sorong. Diakses pada 14 Juli 2021 dari : https://www.nabire.net/lebih-dekat-dengan-suku-moi-darisorong/

Yapsenang, Y. N., \& Usmany, D.P. (2019). Mekanisme Penyelesaian Konflik Tradisional Suku Bangsa Moi (Traditional Solution of Conflict in Moi Tribe). Jurnal Penelitian Arkeologi Papua Dan Papua Barat, 11 (1), 57-69. https://doi.org/10.24832/papua.v11i1.266

Yulia. (2016). Buku Ajar Hukum Adat. Lhokseumawe: Unimal Press.

Yunita, F. E. (2018). Pelepasan Hak Atas Tanah Adat Menjadi Hak Milik Perorangan Pada Suku Moi Di Kabupaten Sorong Provinsi Papua Barat. Tesis. Program Magister Kenotariatan Program Pascasarjana Fakultas Hukum Universitas Islam Indonesia. 